\title{
立足专业做创业 促进科普勇创新
}

\section{一以河北医科大学中西医结合学院大学生创业团队为例}

李文慧

沧州中西医结合医院科研教学区

DOI:10.32629/jief.v2i8.2027

[摘 要] 在众多的大学生创业选题中, 基于学科专业的创新创业实践探索更易形成其核心竞争力, 同时也有利于学科专业的科普教育。本文以 河北医科大学中西医结合学院大学生创业团队创业历程为例，了解并分析立足学科专业做创业的优势，以及其在科学普及教育中发挥的作用。 [关键词] 创新创业; 学科专业; 科学普及

中图分类号: G812 文献标识码：A

在 “大众创业，万众创新”的时代背景下，国内各高校日益重视创 新创业的工作, 积极地进行有益的探索和实践, 在竞争激烈的市场经济 中, 大学生创业者在经验、资金等方面并不占优势, 其核心竞争力多体 现在学科专业方面, 既有专业知识储备, 又有创新创业能力的创业者在 创业实践中更容易保持其持久独特的竞争力。

\section{1 立足学科专业开展创新创业}

1.1 可行性分析

国内许多高校建立大学生创意产业园、创业捊化基地等, 鼓励大学 生结合自己所学专业积极参加创新创业活动, 并在师资、政策、资金等 方面提供支持, 这为大学生创新创业活动提供了外在条件保障。

大学生在其主修的专业领域了解广泛、研究深入, 精通开展与创新 创业实践活动相关专业的知识与技能, 且有专业教师指导, 这为大学生 开展立足学科专业的创新创业活动提供了知识人才保障。

1.2 时代意义

开展立足学科专业的创新创业活动从专业特色出发, 遵循 “学以致 用、知识转化、能力培养、激励创新” 的理念。把创新的思想 “转化” 为解决问题和实践应用的能力, 有利于激发大学生创新意识、提高大学 生科技创新能力、引领大学生自主创业潮流、全面提高学生综合素质。 通过不断丰富创业活动的形式和内容, 进行系统的研究和总结, 有 利于完善大学生创新创业的理论体系, 并在此基础上进一步开展大学生 创业活动的实践探索, 特色鲜明、意义深远、影响深刻。

\section{2 立足学科专业的创业活动对科普的推动作用}

习总书记在讲话中指出: “科技创新和科学普及是实现创新发展的 两翼, 要把科学普及放在与科技创新同等重要的位置。”科学普及与创 新发展相辅相成。

大学生开展立足学科专业的创新创业实践活动的过程中促进知识科 技成果转化, 又会将其学科专业知识进一步应用普及, 有利于 “弘扬科 学精神, 普及科学知识”, 营造崇尚科学的良好社会氛围。 业实践

3 河北医科大学中西医结合学院大学生创业团队开展的特色创

\section{1 立足专业 开展校园创业活动}

河北医科大学中西医结合学院大学生创业团队申报了一项大学生创 新性实验计划项目 《基于中医药文化的大学生创新创业产品的研究与探 索》(USIP2018305)。

本创业项目立足弘扬传统中医药文化, 紧密结合国家对高校实施创 新创业教育改革的任务和要求, 依托中西医结合专业优势和特色, 开展 相关探索。项目实施包括: 注册经营校内实体店; 开展传统中医药特色 疗法体验及康养文化传播; 利用校园特殊节点及中国传统民俗节日, 开 展自制的中医药文化产品的校园展卖; 建设微信公众平台, 打造基于互 联网传播的特色中医药文化载体。

团队的创业理念是：注重普及中医药科普知识, 弘扬中医药传统文 化; 注重紧密结合专业所学, 将中医的 “整体观念, 辩证论治”、“未病 先防” 等基本理论知识应用到创业实践之中; 注重发挥学校优势, 提升 产品文化内涵, 使创业的许多产品都被赋予丰富的中医药文化元素; 注 重依托校外基地做支撑，开创大学生创业校企联合模式。

3.2 普及教育 弘扬中医药文化

随着人们生活水平的提高, 对健康养生日益重视, 越来越多的老师 和同学们希望更加深入了解中医药, 正确认识中医药, 合理使用中医药, 所以团队的创业活动满足了这种日益增长的知识和文化需求。
3. 2.1 依托校内中药栽培园, 建设 “杏林来了” 微信科普平台 通过该微信平台, 一方面加强对中医药科普知识的宣传和引导, 另 一方面及时发布园地活动开展情况, 并就同学们普遍关注的药材养护以 及功效等问题进行答疑解惑。

3.2 .2 依托校内经营实体店, 开设 “中艾堂讲堂” 养生科普课堂

讲解员们就大家所属的 “亚健康状态” 讲解分析。阐述日常生活中 的食物对人体的影响, 提醒和纠正大家平时的一些错误习惯, 针对不同 的体质提出专业养生保健建议等。

3. 3 创业实绩

团队的创业、科普活动深受广大师生喜爱，创业期间接待顾客 10000 多人次, 出售产品 4000 多件, 实现了较好的盈利, 并打造了富有文化底 蕴的创业品牌。

该项目在第四届河北省大学生创新创业年会中荣获特等奖。

4 立足专业的创业活动以及其推动科学普及中存在的问题

4.1 知识经验有待提升

大学生创业团队社会市场经验不足、人脉尚浅, 需要不断提升专业

的行业技能, 强化科普团队，加强人力资源、经营管理等方面的学习。

4.2 资金保障有待支持

资金不足总是制约创新创业的一个瓶颈问题，大学生创业团队在创 业途中常常被资金不足所限制，缺乏经费作为启动资金和后续保障。

4.3 相关政策有待完善

政策支持下的创新创业及科普宣传活动更易取得成功, 大学生创业 的创业动力更充足, 创业活动有保障。

5 给 “立足专业做创业活动以及其推动科学普及发展” 的建议

5.1 提高创业科普队伍素质

创业不仅依靠大学生自身的知识储备、坚韧不拔的精神, 还需聘请 专业教师做全方位培训, 学习先进企业的经验。

5.2 开拓多元化融资渠道

多元化的融资渠道能为立足专业做创业、积极促进专业科普的创业 者们保驾护航。

\section{3 健全创业科普管理体系}

创业科普管理体系的完善, 让大学生创业者们充分利用优惠政策, 减免一定用度，获得政策指引，把控创业方向。

\section{6 结束语}

大学生创新创业实践是 “大众创新, 万众创业” 号召下的产物。立 足学科专业的大学新创新创业、科普活动是其中一个方向, 有利于推动 科技成果的转化，促进学科专业的科普，从而提升全民素质。在创业探 索实践磨练中, 大学生创业者们将知识学以致用, 形成创新思维, 提高 创业能力, 认识、实现自身价值。大学生创业任重而道远，但在国家大 众创业万众创新的时代要求下, 大学生应不畏艰辛, 勇于创新, 敢于创 业，不负青年学子的社会责任与使命担当。

\section{[参考文献]}

[1]何本祥,胡毓诗,丁海丽,沈海,李雪,廖远朋.发展中西医结合运动医 学,助力体育强国建设[J].成都体育学院学报,2019,45(06):17-20.

[2]中国中西医结合学会医学影像专业委员会第十七次全国学术大 会[J].中国中西医结合影像学杂志,2019,17(04):442.

[3]中国中西医结合学会 2019 年度学术活动计划[J].中国中西医结 合杂志, 2019,39(01):125-128. 